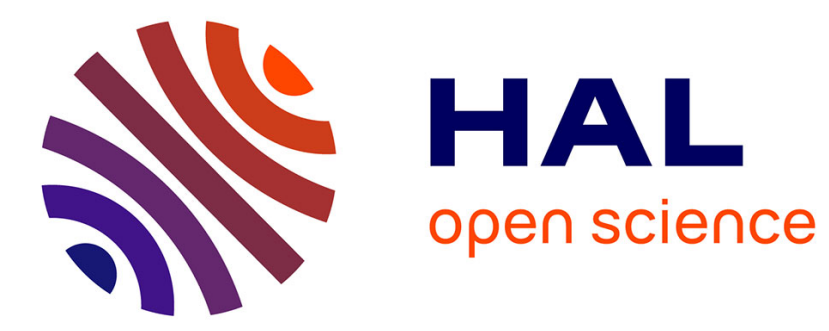

\title{
Estrogen and gastrointestinal malignancy
}

\author{
A.M. Hogan, D. L. Collins, A.W. Baird, D.C. Winter
}

\section{To cite this version:}

A.M. Hogan, D. L. Collins, A.W. Baird, D.C. Winter. Estrogen and gastrointestinal malignancy. Molecular and Cellular Endocrinology, 2009, 307 (1-2), pp.19. 10.1016/j.mce.2009.03.016 . hal00499126

\section{HAL Id: hal-00499126 https://hal.science/hal-00499126}

Submitted on 9 Jul 2010

HAL is a multi-disciplinary open access archive for the deposit and dissemination of scientific research documents, whether they are published or not. The documents may come from teaching and research institutions in France or abroad, or from public or private research centers.
L'archive ouverte pluridisciplinaire HAL, est destinée au dépôt et à la diffusion de documents scientifiques de niveau recherche, publiés ou non, émanant des établissements d'enseignement et de recherche français ou étrangers, des laboratoires publics ou privés. 


\section{Accepted Manuscript}

Title: Estrogen and gastrointestinal malignancy

Authors: A.M. Hogan, D. Collins, A.W. Baird, D.C. Winter

PII:

DOI:

S0303-7207(09)00206-8

Reference: doi:10.1016/j.mce.2009.03.016

To appear in: $\quad$ Molecular and Cellular Endocrinology

Received date: 23-2-2009

Accepted date: $\quad$ 23-3-2009

Please cite this article as: Hogan, A.M., Collins, D., Baird, A.W., Winter, D.C., Estrogen and gastrointestinal malignancy, Molecular and Cellular Endocrinology (2008), doi:10.1016/j.mce.2009.03.016

This is a PDF file of an unedited manuscript that has been accepted for publication. As a service to our customers we are providing this early version of the manuscript. The manuscript will undergo copyediting, typesetting, and review of the resulting proof before it is published in its final form. Please note that during the production process errors may be discovered which could affect the content, and all legal disclaimers that apply to the journal pertain. 


\title{
Estrogen and gastrointestinal malignancy
}

\author{
Hogan $\mathrm{AM}^{12}$, Collins $\mathrm{D}^{12}$, Baird AW ${ }^{2}$, Winter DC ${ }^{1}$. \\ ${ }^{1}$ Institute for Clinical Outcomes Research and Education (iCORE), St. Vincent's \\ University Hospital, Elm Park, Dublin 4, Ireland. \\ ${ }^{2}$ Conway Institute of Biomolecular Sciences and College of Life Sciences, University \\ College Dublin, Ireland.
}

Corresponding Author:

Aisling Hogan,

Institute for Clinical Outcomes Research and Education (iCORE),

St. Vincent's University Hospital,

Elm Park,

Dublin 4.

Email: Aislinghogan@yahoo.com

Tel: 0035312695033 


\title{
Estrogen and gastrointestinal malignancy
}

\author{
$\underline{\text { Key Words: }}$
}

Estrogen, Esophagus, Stomach, Gallbladder, Colon, Malignancy.

\section{Summary:}

The concept that E2 exerts an effect on the gastrointestinal tract is not new and its actions on intestinal mucosa have been investigated for at least three decades. An attempt to consolidate results of these investigations generates more questions than answers, thus suggesting that many unexplored avenues remain and that the full capabilities of this steroid hormone are far from understood. Evidence of its role in esophageal, gastric and gallbladder cancers is confusing and often equivocal. The most compelling evidence regards the protective role conferred by estrogen (or perhaps ER $\beta$ ) against the development and proliferation of colon cancer. Not only has the effect been described but many mechanisms of action have been explored. It is likely that, along with surgery, chemotherapy and radiotherapy, hormonal manipulation will play an integral role in colon cancer management in the very near future.

\section{Introduction:}

Only a few decades ago, it was believed that the primary (and perhaps sole) function of $17 \beta$ estradiol (E2) was in the development of female secondary sexual characteristics and subsequent regulation of reproductive function. However this has been recognised as an over-simplification and there are few organs in which some effect of E2 has not been described. From a neurological perspective, E2 may confer protection against Alzheimer's disease ${ }^{1}$ through its direct action on mitochondrial function. A protective role is described against the development of retinal degenerative disease ${ }^{2}$, improvement of memory ${ }^{3}$, induction of cerebro-vascular accidents $^{4} 5$ and modulation of the sleep-wake cycle ${ }^{6}$. The role of E2 in both development and prognostic prediction in breast ${ }^{7}$ and ovarian cancers 8 is well described and many therapeutic interventions (in the form of receptor modulation) are in widespread use to this effect. Potent estrogenic effects on pulmonary vasculature have been suggested as an explanation for the poorly understood but nonetheless clinically apparent impact of gender in trauma, ischaemia/reperfusion, shock and sepsis. ${ }^{9}$ Epidemiologically, men are more likely to develop colon cancer than women and hormone replacement therapy appears to confer an additive protective role. ${ }^{10} \mathrm{~A}$ similar male predominance is apparent in esophageal and gastric cancers but evidence as to the role of $\mathrm{E} 2$ is less convincing.

\section{Methods:}


A literature search was conducted using the PubMed database and the search terms "estrogen", "estrogen AND cancer" "estrogen AND esophagus" "estrogen AND stomach" "estrogen AND gallbladder" and "estrogen AND gastrointestinal tract". Only studies published in English between 1967 and 2008 were included. Bibliographies of extracted studies were further cross references. In all, 157 full text articles were selected for review.

\section{Estrogen- Mechanism of Action:}

\section{Genomic:}

Members of steroid receptor superfamily (including ER $\alpha$ and ER $\beta$ ) exert their actions through at least two diverse mechanisms- traditional transcriptional regulation of target genes in the nucleus (genomic) or alternative mechanisms initiated at the cell membrane and mediated by secondary messenger proteins (non-genomic) ${ }^{11}$. As with other steroid hormones, estrogens diffuse across cell membranes thus facilitating potential regulation of intracellular (cytoplasm) signalling cascades. Genomic actions involve the binding of estrogen to one of the receptor is forms, translocation to the nucleus, induction of conformational change enabling coupling with estrogen response elements and causing regulation of gene expression. ${ }^{12}$ These transcriptional effects of E2 have a latency of onset of two to eight hours and may be sustained. ${ }^{13}$

\section{Non-Genomic:}

More recently, effects of steroid hormones have been described which are too rapid to be accounted for by altered transcription or translation. These are termed non-nuclear, non-genomic or non-transcriptional effects. A single molecular mechanism has not been elucidated but actions can be considered non-genomic when: (i) they are too rapid to be compatible with RNA and protein synthesis (occur within minutes of exposure to the hormone (ii) they can be reproduced in the presence of inhibitors of RNA or protein synthesis (iii) they can be reproduced by using steroid hormones coupled to cell membrane impermeable molecules (iv) they occur in cells with highly compacted chromatin in which RNA and protein synthesis are absent (spermatozoa) or (iv) they are elicited via steroid hormones binding to receptors containing mutations which make them incapable of activating transcriptional processes. Various secondary messengers at cytoplasmic level have been described as mediators of non-genomic actions of estrogen including protein kinase $\mathrm{C}^{15}$, intracellular calcium ${ }^{16}$, cytosolic cyclic $\mathrm{AMP}^{17}$ and $\mathrm{GMP}^{18}$ nitric oxide ${ }^{19}$ and mitogen activated protein kinase $\mathrm{e}^{20}$. The understanding of the molecular basis of this non-genomic signal transduction is important and may, in the future provide therapeutic windows for various pathological processes.

\section{Estrogen and Esophageal Cancer:}


Esophageal cancer occurs more frequently in men than women ${ }^{21}$ and men progress to invasive carcinoma from Barrett's esophagus at twice the rate of their female counterparts $^{22}$. While ER had been demonstrated in esophageal mucosa in $1983^{23}$, a second isoform of the receptor was described in $1996^{24}$ and this warranted further characterisation and classification its presence in esophageal tissue. The presence of ER- $\beta$ was confirmed by immunohistochemistry in both esophageal adenocarcinoma and Barrett's esophagus cells with and without dysplasia ${ }^{25}$ and it was later demonstrated that, when compared to Barret's metaplasia negative for dysplasia, esophageal adenocarcinoma significantly over expressed ERß.

Animal studies are equivocal, however, regarding the role of E2 in esophageal carcinogenesis. While a protective role of ethinyl estradiol was suggested in the presence of $0.1 \% \mathrm{~N}$-ethyl-N-hydroxyethylnitrosamine ${ }^{27}$ the same paper demonstrated a decrease in esophageal hyperplasia in rats pre-treated with $0.03 \% \mathrm{~N}$ nitrosopiperidine. The first convincing description of estrogenic inhibition of esophageal cancer proliferation was in a cell line cultured from metastatic esophageal tissue. ${ }^{28}$ An absolute response of this cell line (named KSE-1) was higher than that of human mammary carcinoma cells but lower than that of non-malignant human mammary epithelial cells. Inhibition of KSE-1 cell growth was dose dependant at maximum concentrations as low as $10^{-12} \mathrm{mg} / \mathrm{ml}$ oestradiol. A few years later an estradiol sensitivity assay for use in oesophageal and breast cancer cell lines was developed. ${ }^{29}$ Again growth inhibition of KSE-1 cells was demonstrated and an affinity of $4.2 \mathrm{fmol} / \mathrm{mg}$ for estrogen receptors was described.

A Swedish epidemiological study examined males undergoing hormonal manipulation for treatment of prostate cancer (increased estrogen and decreased testosterone level) and its potential reduction of risk of developing esophageal carcinoma. ${ }^{30} \mathrm{~A}$ total of 100,215 patients were followed up for an average of 4 years. Relative risk was calculated. No correlation, however, was evident between hormonal manipulation and the relative risk of developing adenocarcinoma of the esophagus. Thus, despite a male prevalence in the incidence of esophageal carcinoma, no convincing evidence has been presented in animal or population studies and it appears less than likely that E2 per se is protective against esophageal cancer.

\section{Estrogen and Gastric Cancer:}

Epidemiological studies of the incidence and prevalence of gastric cancer also show a worldwide male: female predominance in the order of at least $2: 1{ }^{31}$ It is believed that some (not yet fully elucidated) role is played by female sex hormones in the process of gastric carcinogenesis. ${ }^{32}$ It has been suggested that, not unlike breast cancer, later age at menarche ${ }^{33}$, older menopause, and nulliparity ${ }^{34}$ are associated with increased risk of development of gastric carcinoma in women. Japanese findings, however, were not consistent with this and they concluded that although early estrogen exposure may have some protective effect, female reproductive factors have no substantial influence on gastric cancer development. ${ }^{35}$ Female, castrated-male and estrogen-treated male rats do, however have a lower incidence of chemically induced gastric cancer with lower histological differentiation than non-treated male rats ${ }^{36}$ and estrogen receptors have been isolated in many but not all gastric adenocarcinomas. ${ }^{37} 38$ Comparison of presence of estradiol in intracellular spaces of cancerous and non-cancerous gastric epithelium using the avidin- biotin peroxidase complex and immunohistochemistry 
revealed that estradiol was present only in the cytoplasm of cancer cells, and most commonly in those with scirrhous growth pattern. ${ }^{39}$

Positive nuclear estrogen receptor immunoreactivity (ER-IR) or detection of D5 antibody (an estrogen receptor related protein) confers a worse prognosis ${ }^{40}{ }^{41}$, more widespread lymph node involvement ${ }^{42}$, increased metastatic potential (specifically ER- $\beta$ isoform $)^{43}$ and has been previously correlated with a significantly lower 10 year cumulative survival. ${ }^{44}$ The true impact of the presence or absence of ER on survival has, however been challenged ${ }^{45}$ and, with use of modified techniques (dextran coated charcoal assay ${ }^{46}$ or flow cytometry ${ }^{47}$ ), no correlation between ER positivity and grade, no difference in expression between cancerous and normal mucosa and no impact on survival was demonstrated. Geographical inconsistencies have also been reported. ${ }^{48}$ The true prognostic value of the presence or absence of ER in malignant gastric mucosa remains to be elucidated and it may be that presence of ER is a feature of normal mucosa rather than a function of malignancy. Perhaps available methods are not yet sufficiently refined to differentiate ER with absolute certainty but, despite this the evidence for the prognostic role of cathepsin D (an estrogen-regulated lysosomal protease $)^{49}$ is convincing.

The fact that ER binding sites have almost identical biochemical characteristics to those of breast and endometrial cancers is, however, highly suggestive of an equivalent hormonal dependency of gastric cancer. ${ }^{50}$ Following the description of ER$\beta$ isoform by Kuiper ${ }^{24}$ and presentation of unequivocal evidence of the presence of ER almost ubiquitously throughout the gastrointestinal mucosa, interest was re-ignited in its potential role in gastric adenocarcinoma and indeed, the presence of ER- $\beta$ (in normal and abnormal gastric mucosa) was confirmed and a functional role in carcinogenesis suggested. ${ }^{51}$ Perhaps it was the presence of various previously undescribed ER isoforms that created technical difficulty in their detection and so led to inconsistencies in results.

An effort to translate this new found knowledge of the role of receptors to therapeutic use was unsuccessful as, not only did estrogen stimulate growth in gastric cancer cell lines but so did its partial-agonist 4-hydroxytamoxifen. ${ }^{52}$ Further evidence was provided in a randomised control trial that ER positivity conferred a worse prognosis but disappointingly the administration of tamoxifen at therapeutic concentrations did not prolong survival. ${ }^{53}$ Conversely, more recent evidence suggests that patients treated with tamoxifen may have an overall increased risk of development of gastric carcinoma and a shorter latency period between the diagnosis of breast and gastric cancer. $^{54} \mathrm{~A}$ Chinese group ${ }^{55}$ hypothesised that, since the amplification of c-erbB-2 oncogene $^{56}$ and its overexpression had been implicated in the advancement of gastric carcinoma, and estrogen was known to inhibit its expression in breast cancer cell lines, perhaps estrogen itself could be administered as a reasonable therapeutic option for the treatment of gastric cancer. Soon afterwards a Swedish nationwide cohort study examined the incidence of gastric cancer in men with prostate cancer treated between 1950 and 1980 (when estrogen was the treatment of choice). ${ }^{57}$ Those exposed to therapeutic exogenous estrogens demonstrated a reduced incidence of gastric cancer when compared to an age and sex matched population.

Much controversy and diversity exists among findings pertaining to the role of estrogen in the development of gastric cancer. However, a few certainties prevail throughout the decades: (i) Some protective role appears to be afforded to women against the development of gastric carcinoma when compared to age matched male counterparts, (ii) ER (ß) has been isolated in gastric carcinoma mucosa, (iii) Both estrogen and progesterone cause proliferation in gastric cancer cell lines. What 
remains to be investigated is the true gradient in ER expression between malignant and normal gastric mucosa and whether or not it carries a true clinical significance.

\section{Estrogen and gallbladder cancer:}

Because of the low incidence of gallbladder cancer worldwide, studies tend to be small and many are inconclusive. A link between a woman's age of first parity and risk of developing gallbladder cancer has been suggested (reported that $1^{\text {st }}$ parity under 25 increases risk but over 30 confers protective effects $)^{58}$. However, this appears to be an isolated finding in a single retrospective study and has not been validated since. Estrogen receptor positivity in gallbladder cancer, when assessed with a specific immunohistochemistry assay, was only weakly positive and felt to be of questionable clinical significance. ${ }^{59}$ Poorly differentiated tumours may, however, be more likely to be receptor negative ${ }^{60}$, and evidence is increasing as to the correlation of negative expression of ER $\beta$ with increased metastatic potential ${ }^{61}{ }^{62}$ but, again, the therapeutic implications are uncertain. A small Italian study demonstrated a link between the use of postmenopausal hormone replacement therapy and an increased risk of gallbladder cancer $\left(n=31\right.$; Odds Ratio 3.2). ${ }^{63}$ However, this has not been shown elsewhere.

\section{Estrogen and colon cancer}

Colorectal cancer, like gastric and esophageal, shows considerable predilection for the male sex. Furthermore, gender differences exist between type of cancer and location within the colon with women displaying a higher relative incidence of right sided tumours compared to men. ${ }^{64}$ The lower incidence of colon cancer in pre-menopausal women $^{65}$ has been attributed to the protective effect of estrogen and this is supported by the widely recognised prolonged protection afforded by hormone replacement therapy in the post-menopausal age-group. ${ }^{66}$ Kuiper's description of a novel ER isoform ${ }^{37}$ (ER $\beta$ ) in 1996 incited a resurgence of interest in the previously unexplained preventative role of female sex hormones against development of colon cancer. This new isoform has been shown by in situ hybridisation techniques ${ }^{67}$ to be more widely expressed in colonic epithelium than ER $\alpha$ and is thus felt to be responsible for anti-proliferative estrogenic effects on the colonic mucosa. Higher ER $\beta$ expression has been shown to confer survival advantage in patients ${ }^{68}$ and increase viability in cell lines ${ }^{69}$ and lower expression appears to mirror tumour dedifferentiation ${ }^{70}$ in human and animal models ${ }^{71}$.

Many theories exist as to the mechanism of this protective action of ER $\beta$ on colonic mucosa and it is probably most likely that the effect is exerted through interaction of a variety of concomitant events- both genomic and non-genomic. One hypothesis is that ER $\beta$ exerts a genomic action independent of E2 and this was substantiated by a study in which human-colon-tumour-118 cells demonstrated only $20 \%$ of normal proliferation related to the expression of cyclin $\mathrm{E}$ and cyclin-dependant kinase inhibitor $1 \mathrm{~A}$ in the absence of estrogen. ${ }^{72}$ It was surmised that these effects may have been mediated by epidermal growth factor or insulin like growth factor 1. Much debate exists as to how ER $\beta$ induces apoptosis in colon cancer cells and potential mechanisms that have been described include increased DNA fragmentation ${ }^{73}$, increased p53 signalling ${ }^{74}$ and induction of a caspase dependant pro-apoptotic cascade. $^{75}$ 
Rapid non-genomic actions are the subject of much research worldwide and because uncertainty exists as to what exact cellular messaging cascades are involved in these non-genomic events, a wide variety of mediators have been examined. Whether or not classical estrogen receptors are involved in this rapid signalling is uncertain but a membrane bound receptor (which is dependant on palmitoylation for localisation) has been described ${ }^{76}$ and is likely involved. It is not known whether ER $\beta$ migration to the cell membrane accounts for these actions or whether an entirely different receptor isoform exerts the effects. ${ }^{77}$ Furthermore, some evidence exists as to non-genomic actions that occur independently of any known receptor, as proven by a rapid calcium flux in ER negative SKBR-3 cells when exposed to E2 ${ }^{78}$. It is felt that protein kinase $\mathrm{C}$ is a most likely involved in mediation of this rapid action. Further putative mechanisms of actions include p38 mitogen activated protein kinase leading to caspase- 3 dependant apoptosis ${ }^{79}$, increased expression of vitamin D receptor mediated by mitogen activated protein kinase 1 or $3^{80}$ or ER $\beta$ activation of p38 mitogen activated protein kinase cascade $^{81}$. Unlike esophagus, stomach or gallbladder, evidence of protective effects of estrogen against colorectal cancer is compelling. Current controversies in the literature focus primarily on the mechanism(s) of these actions. When these are fully elucidated, it is likely that hormonal manipulation will provide as vital a role in the management of colon cancer as it currently does in breast and prostate disease.

\section{Discussion:}

The concept that E2 exerts an effect on the gastrointestinal tract is not new and its actions on intestinal mucosa have been investigated for at least three decades. An attempt to consolidate results of these investigations generates more questions than answers, thus suggesting that many unexplored avenues remain and that the full capabilities of this steroid hormone are far from understood. While it appears intuitive that E2 is protective against esophageal cancer (higher incidence and worse prognosis in men), this hypothesis is supported by neither laboratory nor epidemiological studies. Undoubtedly, estrogens are somehow implicated in the development of gastric cancer (supported by both cell work and population studies) but therapeutic potential of either E2 or its antagonists remains undescribed despite much investigation. In the gallbladder, further controversy exists in that, although malignant mucosa has stained positive for ER, no significant correlation with cancer free survival or metastatic potential has been proven. (Table 1) The most convincing and compelling evidence regards the protective role conferred by estrogen (or perhaps $E R \beta$ ) against the development and proliferation of colon cancer. Not only has the effect been described but many mechanisms of action have been explored. It is likely that, along with surgery, chemotherapy and radiotherapy, hormonal manipulation will play an integral role in colon cancer management in the very near future. 


\section{References:}

1 Brinton RD. Estrogens regulation of glucose metabolism and mitochondrial function: therapeutic implications for prevention of Alzheimer's disease. Adv Drug Deliv Rev. 2008;60(13-14):1504-11.

${ }^{2}$ Maneesh Kumar D, Simpkins JW, Agarwal N. Estrogens and neuroprotection in retinal diseases. Molecular Vision 2008; 14: 1480-1486.

${ }^{3}$ Hojo Y, Murakami G, Mukai H, Higo S, Hatanaka Y, Ogiue-Ikeda M, Ishii H, Kimoto T, Kawato S. Estrogens synthesis in the brain--role in synaptic plasticity and memory. Mol Cell Endocrinol. 2008;290(1-2):31-43.

${ }^{4}$ Sare GM, Gray LJ, Bath PM. Association between hormone replacement therapy and subsequent arterial and venous vascular events: a meta-analysis. Eur Heart J. 2008;29(16):2031-41.

${ }^{5}$ Birge SJ. Hormone therapy and stroke. Clin Obstet Gynecol. 2008;51(3):581-91

${ }^{6}$ Deurveilher S, Cumyn EM, Peers T, Rusak B, Semba K. Estradiol replacement enhances sleep deprivation-induced c-Fos immunoreactivity in forebrain arousal regions of ovariectomized rats. Am J Physiol Regul Integr Comp Physiol. 2008;295(4):R1328-40.

7 Jick SS, Hagberg KW, Kaye JA, Jick H. Postmenopausal estrogen-containing hormone therapy and the risk of breast cancer. Obstet Gynecol. 2009;113(1):74-80.

${ }^{8}$ Suzuki F, Akahira J, Miura I, Suzuki T, Ito K, Hayashi S, Sasano H, Yaegashi N. Loss of estrogen receptor beta isoform expression and its correlation with aberrant DNA methylation of the 5'-untranslated region in human epithelial ovarian carcinoma. Cancer Sci. 2008;99(12):2365-72.

${ }^{9}$ Lahm T, Crisostomo PR, Markel TA, Wang M, Weil BR, Novotny NM, Meldrum DR. The effects of estrogen on pulmonary artery vasoreactivity and hypoxic pulmonary vasoconstriction: potential new clinical implications for an old hormone. Crit Care Med. 2008;36(7):2174-83.

${ }^{10}$ Kennelly R, Kavanagh DO, Hogan AM, Winter DC. Oestrogen and the colon: potential mechanisms for cancer prevention. Lancet Oncol. 2008;9(4):385-91.

${ }^{11}$ Winter DC, Taylor C, C O'Sullivan G, Harvey BJ. Mitogenic effects of oestrogen mediated by a non-genomic receptor in human colon. Br J Surg. 2000;87(12):1684-9.

${ }^{12}$ Simoncini T, Genazzani AR. Non-genomic actions of sex steroid hormones. Eur J Endo. 2003;148:281-292.

${ }^{13}$ Harvey BJ, Doolan CM, Condliffe SB, Renard C, Alzamora R, Urbach V. Nongenomic convergent and divergent signalling of rapid responses to aldosterone and estradiol in mammalian colon. Steroids. 2002;67(6):483-91.

${ }^{14}$ Moggs JG, Orphanides G. Estrogen receptors: Orchestrators of pleiotropic cellular responses. EMBO Report. 2001(2); 775-781.

${ }^{15}$ Alzamora R, Harvey BJ. Direct binding and activation of protein kinase $\mathrm{C}$ isoforms by steroid hormones. Steroids. 2008 Oct;73(9-10):885-8. 
16 Muchekehu RW, Harvey BJ. 17beta-estradiol rapidly mobilizes intracellular calcium from ryanodine-receptor-gated stores via a PKC-PKA-Erk-dependent pathway in the human eccrine sweat gland cell line NCL-SG3. Cell Calcium. 2008;44(3):276-88.

${ }^{17}$ Doolan CM, Condliffe SB, Harvey BJ. Rapid non-genomic activation of cytosolic cyclic AMP-dependent protein kinase activity and $[\mathrm{Ca}(2+)](\mathrm{i})$ by 17 beta-oestradiol in female rat distal colon. Br J Pharmacol. 2000;129(7):1375-86.

${ }^{18}$ Ropero AB, Fuentes E, Rovira JM, Ripoll C, Soria B, Nadal A. Non-genomic actions of 17 beta-oestradiol in mouse pancreatic beta-cells are mediated by a cGMPdependent protein kinase. J Physiol. 1999:1;521 Pt 2:397-407.

${ }^{19}$ Simoncini T, Varone G, Fornari L, Mannella P, Luisi M, Labrie F, Genazzani AR. Genomic and nongenomic mechanisms of nitric oxide synthesis induction in human endothelial cells by a fourth-generation selective estrogen receptor modulator. Endocrinology. 2002;143(6):2052-61.

${ }^{20}$ Hennessy BA, Harvey BJ, Healy V. 17beta-Estradiol rapidly stimulates c-fos expression via the MAPK pathway in T84 cells. Mol Cell Endocrinol. 2005:14;229(1-2):39-47.

${ }^{21}$ Cook MB, Wild CP, Forman D. A systematic review and meta-analysis of the sex ratio for Barrett's esophagus, erosive reflux disease, and nonerosive reflux disease. Am J Epidemiol. 2005:1;162(11):1050-61.

${ }^{22}$ Yousef F, Cardwell C, Cantwell MM, Galway K, Johnston BT, Murray L. The incidence of esophageal cancer and high-grade dysplasia in Barrett's esophagus: a systematic review and meta-analysis. Am J Epidemiol. 2008:1;168(3):237-49.

23 Winborn WB, Sheridan PJ, McGill HC Jr. Autoradiographic demonstration of estrogen receptors in the esophagus. Gastroenterology. 1983 Jun;84(6):1563-7.

${ }^{24}$ Kuiper GG, Enmark E, Pelto-Huikko M, Nilsson S, Gustafsson JA. Cloning of a novel receptor expressed in rat prostate and ovary. Proc Natl Acad Sci U S A. 1996;93(12):5925-30.

${ }^{25}$ Akgun H, Lechago J, Younes M. Estrogens receptor-beta is expressed in Barrett's metaplasia and associated adenocarcinoma of the esophagus. Anticancer Res. 2002;22(3):1459-61.

26 Tiffin N, Suvarna SK, Trudgill NJ, Riley SA. Sex hormone receptor immunohistochemistry staining in Barrett's oesophagus and adenocarcinoma. Histopathology. 2003;42(1):95-6.

${ }^{27}$ Shirai T, Tsuda H, Ogiso T, Hirose M, Ito N. Organ specific modifying potential of ethinyl estradiol on carcinogenesis initiated with different carcinogens. Carcinogenesis. 1987;8(1):115-9.

${ }^{28}$ Matsuoka H, Sugimachi K, Ueo H, Kuwano H, Nakano S, Nakayama M. Sex hormone response of a newly established squamous cell line derived from clinical esophageal carcinoma. Cancer Res. 1987:1;47(15):4134-40.

${ }^{29}$ Matsuoka H, Ueo H, Yano K, Kido Y, Shirabe K, Mitsudomi T, Sugimachi K. Estradiol sensitivity test using contact-sensitive plates of confluent BALB/c 3T3 cell monolayers. Cancer Res. 1990:1;50(7):2113-8.

${ }^{30}$ Lagergren J, Nyrén O. Do sex hormones play a role in the etiology of esophageal adenocarcinoma? A new hypothesis tested in a population-based cohort of prostate cancer patients. Cancer Epidemiol Biomarkers Prev. 1998;7(10):913-5.

${ }^{31}$ Brenner H, Rothenbacher D, Arndt V. Epidemiology of stomach cancer. Methods Mol Biol. 2009;472:467-77. 
${ }^{32}$ La Vecchia C, D'Avanzo B, Franceschi S, Negri E, Parazzini F, Decarli A. Menstrual and reproductive factors and gastric-cancer risk in women. Int J Cancer. 1994:15;59(6):761-4.

${ }^{33}$ Frise S, Kreiger N, Gallinger S, Tomlinson G, Cotterchio M. Menstrual and reproductive risk factors and risk for gastric adenocarcinoma in women: findings from the canadian national enhanced cancer surveillance system. Ann Epidemiol. 2006;16(12):908-16.

${ }^{34}$ Freedman ND, Chow WH, Gao YT, Shu XO, Ji BT, Yang G, Lubin JH, Li HL, Rothman N, Zheng W, Abnet CC. Menstrual and reproductive factors and gastric cancer risk in a large prospective study of women. Gut. 2007;56(12):1671-7.

${ }^{35}$ Persson C, Inoue M, Sasazuki S, Kurahashi N, Iwasaki M, Ye W, Tsugane S; JPHC Study Group. Female reproductive factors and the risk of gastric cancer in a largescale population-based cohort study in Japan (JPHC study). Eur J Cancer Prev. 2008;17(4):345-53.

${ }^{36}$ Furukawa H, Iwanaga T, Koyama H, Taniguchi H. Effect of sex hormones on the experimental induction of cancer in rat stomach - a preliminary study. Digestion. 1982;23(3):151-5.

${ }^{37}$ Sica V, Nola E, Contieri E, Bova R, Masucci MT, Medici N, Petrillo A, Weisz A, Molinari AM, Puca GA. Estradiol and progesterone receptors in malignant gastrointestinal tumors. Cancer Res. 1984;44(10):4670-4.

${ }^{38}$ Tokunaga A, Nishi K, Matsukura N, Tanaka N, Onda M, Shirota A, Asano G, Hayashi K. Estrogen and progesterone receptors in gastric cancer. Cancer. 1986 $1 ; 57(7): 1376-9$

${ }^{39}$ Nishi K, Tokunaga A, Shimizu Y, Yoshiyuki T, Wada M, Matsukura N, Tanaka N, Onda M, Asano G. Immunohistochemical study of intracellular estradiol in human gastric cancer. Cancer. 1987:1;59(7):1328-32.

${ }^{40}$ Yokozaki H, Takekura N, Takanashi A, Tabuchi J, Haruta R, Tahara E. Estrogens receptors in gastric adenocarcinoma: a retrospective immunohistochemical analysis. Virchows Arch A Pathol Anat Histopathol. 1988;413(4):297-302.

${ }^{41}$ Harrison JD, Jones JA, Ellis IO, Morris DL. Oestrogen receptor D5 antibody is an independent negative prognostic factor in gastric cancer. Br J Surg. 1991;78(3):334-6. ${ }^{42}$ Zhao XH, Gu SZ, Liu SX, Pan BR. Expression of estrogen receptor and estrogen receptor messenger RNA in gastric carcinoma tissues. World $\mathrm{J}$ Gastroenterol. 2003;9(4):665-9.

${ }^{43}$ Takano N, Iizuka N, Hazama S, Yoshino S, Tangoku A, Oka M. Expression of estrogen receptor-alpha and -beta mRNAs in human gastric cancer. Cancer Lett. 2002:25;176(2):129-35.

${ }^{44}$ Matsui M, Kojima O, Kawakami S, Uehara Y, Takahashi T. The prognosis of patients with gastric cancer possessing sex hormone receptors. Surg Today. 1992;22(5):421-5.

45 Singh S, Poulsom R, Wright NA, Sheppard MC, Langman MJ. Differential expression of oestrogen receptor and oestrogen inducible genes in gastric mucosa and cancer. Gut. 1997;40(4):516-20.

${ }^{46} \mathrm{Wu} \mathrm{CW}$, Tsay SH, Chang TJ, Chang HM, Hsieh MC, Lui WY, P'eng FK, Chi CW. Clinicopathologic comparisons between estrogen receptor-positive and -negative gastric cancers. J Surg Oncol. 1992;51(4):231-5.

${ }^{47}$ Karat D, Brotherick I, Shenton BK, Scott D, Raimes SA, Griffin SM. Expression of oestrogen and progesterone receptors in gastric cancer: a flow cytometric study. $\mathrm{Br} \mathrm{J}$ Cancer. 1999;80(8):1271-4. 
${ }^{48}$ Cui G, Yuan A, Qvigstad G, Waldum HL. Estrogens receptors are not expressed in esophagogastric carcinomas that come from a high incidence area of China. Hepatogastroenterology. 2001;48(39):594-5.

${ }^{49}$ Ikeguchi M, Fukuda K, Oka S, Yamaguchi K, Hisamitsu K, Tsujitani S, Sakatani T, Ueda T, Kaibara N. Clinicopathological significance of cathepsin D expression in gastric adenocarcinoma. Oncology. 2001;61(1):71-8.

${ }^{50}$ Matsui M, Kojima O, Uehara Y, Takahashi T. Characterization of estrogen receptor in human gastric cancer. Cancer. 1991:15;68(2):305-8.

${ }^{51}$ Matsuyama S, Ohkura Y, Eguchi H, Kobayashi Y, Akagi K, Uchida K, Nakachi K, Gustafsson JA, Hayashi S. Estrogens receptor beta is expressed in human stomach adenocarcinoma. J Cancer Res Clin Oncol. 2002;128(6):319-24.

${ }^{52}$ Harrison JD, Watson S, Morris DL. The effect of sex hormones and tamoxifen on the growth of human gastric and colorectal cancer cell lines. Cancer. 1989: $1 ; 63(11): 2148-51$.

${ }^{53}$ Harrison JD, Morris DL, Ellis IO, Jones JA, Jackson I. The effect of tamoxifen and estrogen receptor status on survival in gastric carcinoma. Cancer. 1989:1;64(5):100710.

${ }^{54}$ Chandanos E, Lindblad M, Rubio CA, Jia C, Warner M, Gustafsson JA, Lagergren $\mathrm{J}$. Tamoxifen exposure in relation to gastric adenocarcinoma development. Eur J Cancer. 2008;44(7):1007-14.

${ }^{55} \mathrm{Wu} \mathrm{CW}$, Lui WY, P'eng FK, Chi CW. Hormonal therapy for stomach cancer. Med Hypotheses. 1992;39(2):137-9.

${ }^{56}$ Tian XS, Zhou WH, Wu GJ, Sun JZ, Cong MH. Inhibitive effects of mifepristone on growth of breast cancer: experiment with rats. Zhonghua Yi Xue Za Zhi. 2008 26;88(8):559-63.

${ }^{57}$ Lindblad M, Ye W, Rubio C, Lagergren J. Estrogens and risk of gastric cancer: a protective effect in a nationwide cohort study of patients with prostate cancer in Sweden. Cancer Epidemiol Biomarkers Prev. 2004;13(12):2203-7.

${ }^{58}$ Lambe M, Trichopoulos D, Hsieh CC, Ekbom A, Adami HO, Pavia M. Parity and cancers of the gall bladder and the extrahepatic bile ducts. Int J Cancer. 1993 30;54(6):941-4.

${ }^{59}$ Ko CY, Schmit P, Cheng L, Thompson JE. Estrogens receptors in gallbladder cancer: detection by an improved immunohistochemical assay. Am Surg. 1995 ;61(10):930-3.

${ }^{60}$ Malik IA, Abbas Z, Shamsi Z, Daudi I, Shah HA, Moid I, Khan ZK, Shaikh H. Immuno-histochemical analysis of estrogen receptors on the malignant gallbladder tissue. J Pak Med Assoc. 1998;48(5):123-6.

${ }^{61}$ Sumi K, Matsuyama S, Kitajima Y, Miyazaki K. Loss of estrogen receptor beta expression at cancer front correlates with tumor progression and poor prognosis of gallbladder cancer. Oncol Rep. 2004;12(5):979-84.

${ }^{62}$ Park JS, Jung WH, Kim JK, Hwang HK, Cho SI, Yoon DS, Chi HS, Kim BR. Estrogens Receptor alpha, Estrogens Receptor beta, and Progesterone Receptor as Possible Prognostic Factor in Radically Resected Gallbladder Carcinoma. J Surg Res. 2008. Epub.

${ }^{63}$ Gallus S, Negri E, Chatenoud L, Bosetti C, Franceschi S, La Vecchia C. Postmenopausal hormonal therapy and gallbladder cancer risk. Int J Cancer. 2002: 10;99(5):762-3.

${ }^{64}$ Jemal A, Siegel R, Ward E, Hao Y, Xu J, Murray T, Thun MJ. Cancer statistics, 2008. CA Cancer J Clin. Epub 2008 
${ }^{65}$ Ries LA, Wingo PA, Miller DS, Howe HL, Weir HK, Rosenberg HM, Vernon SW, Cronin K, Edwards BK. The annual report to the nation on the status of cancer, 19731997, with a special section on colorectal cancer. Cancer. 2000:15;88(10):2398-424.

${ }^{66}$ Rossouw JE, Anderson GL, Prentice RL, LaCroix AZ, Kooperberg C, Stefanick ML, Jackson RD, Beresford SA, Howard BV, Johnson KC, Kotchen JM, Ockene J; Writing Group for the Women's Health Initiative Investigators. Risks and benefits of estrogen plus progestin in healthy postmenopausal women: principal results From the Women's Health Initiative randomized controlled trial. JAMA. 2002:17;288(3):32133.

${ }^{67}$ Enmark E, Pelto-Huikko M, Grandien K, Lagercrantz S, Lagercrantz J, Fried G, Nordenskjöld M, Gustafsson JA. Human estrogen receptor beta-gene structure, chromosomal localization, and expression pattern. J Clin Endocrinol Metab. 1997;82(12):4258-65.

${ }^{68}$ Foley EF, Jazaeri AA, Shupnik MA, Jazaeri O, Rice LW. Selective loss of estrogen receptor beta in malignant human colon. Cancer Res. 2000;60(2):245-8.

${ }^{69}$ Qiu Y, Waters CE, Lewis AE, Langman MJ, Eggo MC. Oestrogen-induced apoptosis in colonocytes expressing oestrogen receptor beta. $\mathrm{J}$ Endocrinol. 2002;174(3):369-77.

${ }^{70}$ Konstantinopoulos PA, Kominea A, Vandoros G, Sykiotis GP, Andricopoulos P, Varakis I, Sotiropoulou-Bonikou G, Papavassiliou AG. Oestrogen receptor beta (ERbeta) is abundantly expressed in normal colonic mucosa, but declines in colon adenocarcinoma paralleling the tumour's dedifferentiation. Eur $\mathrm{J}$ Cancer. 2003;39(9):1251-8.

${ }^{71}$ Francesca C, Taddei A, Degl $\square$ innocenti DR, Buccoliero AM, Bechi P, Garbini F, Gheri CF, Moncini D, Cavallina G, Marascio L, Freschi G, Taddei GL Expression of Estrogens beta Receptors in Colon Cancer Progression. Diagn Mol Pathol. 2007. [Epub ahead of print]

${ }_{72}$ Martineti V, Picariello L, Tognarini I, Carbonell Sala S, Gozzini A, Azzari C, Mavilia C, Tanini A, Falchetti A, Fiorelli G, Tonelli F, Brandi ML. ERbeta is a potent inhibitor of cell proliferation in the HCT8 human colon cancer cell line through regulation of cell cycle components. Endocr Relat Cancer. 2005;12(2):455-69.

${ }^{73}$ Xie LQ, Yu JP, Luo HS. Expression of estrogen receptor beta in human colorectal cancer. World J Gastroenterol. 2004;10(2):214-7.

${ }^{74}$ Hsu HH, Cheng SF, Wu CC, Chu CH, Weng YJ, Lin CS, Lee SD, Wu HC, Huang CY, Kuo WW. Apoptotic effects of over-expressed estrogen receptor-beta on LoVo colon cancer cell is mediated by p53 signalings in a ligand-dependent manner. Chin $\mathrm{J}$ Physiol. 2006;49(2):110-6.

${ }^{75}$ Marino M, Galluzzo P, Ascenzi P. Estrogens signaling multiple pathways to impact gene transcription. Curr Genomics. 2006;7(8):497-508

${ }^{76}$ Galluzzo P, Caiazza F, Moreno S, Marino M. Role of ERbeta palmitoylation in the inhibition of human colon cancer cell proliferation. Endocr Relat Cancer. 2007;14(1):153-67

${ }^{77}$ Doolan CM, Harvey BJ. A Galphas protein-coupled membrane receptor, distinct from the classical oestrogen receptor, transduces rapid effects of oestradiol on $[\mathrm{Ca} 2+] \mathrm{i}$ in female rat distal colon. Mol Cell Endocrinol. 2003;199(1-2):87-103.

${ }^{78}$ Pedram A, Razandi M, Levin ER. Nature of functional estrogen receptors at the plasma membrane. Mol Endocrinol. 2006;20(9):1996-2009. 
${ }^{79}$ Marino M, Galluzzo P, Leone S, Acconcia F, Ascenzi P. Nitric oxide impairs the 17beta-estradiol-induced apoptosis in human colon adenocarcinoma cells. Endocr Relat Cancer. 2006;13(2):559-69.

${ }^{80}$ Gilad LA, Schwartz B. Association of estrogen receptor beta with plasmamembrane caveola components: implication in control of vitamin D receptor. J Mol Endocrinol. 2007 ;38(6):603-18.

${ }^{81}$ Caiazza F, Galluzzo P, Lorenzetti S, Marino M. 17Beta-estradiol induces ERbeta up-regulation via p38/MAPK activation in colon cancer cells. Biochem Biophys Res Commun. 2007;359(1):102-7. 


\begin{tabular}{|c|c|c|c|c|}
\hline & Cells & Animals & Epidemiology & Reference \\
\hline Oesophagus & $\begin{array}{l}\text { Growth } \\
\text { Inhibition of } \\
\text { KSE-1 Cells }\end{array}$ & Equivocal & $\begin{array}{l}\text { Male }>\text { Female } \\
\text { No correlation } \\
\text { with hormonal } \\
\text { manipulation }\end{array}$ & $21,27,28$. \\
\hline Stomach & $\begin{array}{l}\text { Stimulation of } \\
\text { gastric cell } \\
\text { growth (as did } \\
\text { agonist } \\
\text { tamoxifen) }\end{array}$ & $\begin{array}{l}\text { Lower } \\
\text { incidence in } \\
\text { female and } \\
\text { castrated rats. }\end{array}$ & Male>Female & $31,36,52$ \\
\hline Gallbladder & $\begin{array}{l}\text { Correlation } \\
\text { between } \\
\text { expression of } \\
\text { ER } \beta \text { and poor } \\
\text { tumour } \\
\text { differentiation. }\end{array}$ & - & $\begin{array}{l}\text { Increased risk } \\
\text { with } \\
\text { postmenopausal } \\
\text { HRT use }\end{array}$ & $61,62,63$ \\
\hline Colon & $\begin{array}{l}\text { Decreased } \\
\text { proliferation } \\
(80 \%) \text { in } \\
\text { human-colon- } \\
\text { tumour-118 } \\
\text { cells in the } \\
\text { presence of } \\
\text { estrogen }\end{array}$ & $\begin{array}{l}\text { Decreased } \\
\text { expression of } \\
\text { ER } \beta \text { in higher } \\
\text { disease stage } \\
\text { in mice }\end{array}$ & $\begin{array}{l}\text { Premenopausal } \\
\text { female }< \\
\text { Postmenopausal } \\
\text { female }<\text { Male }\end{array}$ & $65,66,71,72$ \\
\hline
\end{tabular}

Table 1. Summary of Estrogenic effects on gastrointestinal malignancy. 